\title{
Paradoxes of Resilience: A Review of the World Disasters Report 2016
}

\section{Tom Scott-Smith}

\section{IFRC, World Disasters Report 2016 'Resilience: Saving Lives Today, Investing for Tomorrow'. Geneva: International Federation of Red Cross and Red Crescent Societies, 2016. 282 pp. Available for download: http://www.ifrc.org}

'Resilience', wrote Mark Neocleous in 2012, 'has in the last decade become one of the key political categories of our time. It falls easily from the mouths of politicians, a variety of state departments are funding research into it, urban planners are now obliged to take it into consideration, and academics are falling over themselves to conduct research on it' (Neocleous, 2013: 3). This is one of the few points of agreement in the literature around resilience: it is a big word with big implications. In fact, Neocleous put it relatively mildly. Resilience has reached beyond politicians, state departments, urban planners, and academics to capture the imagination of psychotherapists, child development experts, ecologists and security forces. 'Much like the concept of globalization that rose to popularity in the 1980s and 1990s', concluded a recent issue of Politics, 'resilience seems to carry a productive ambiguity that both resists exact definition and allows for a spectrum of interactions and engagements between policy and the everyday’ (Brassett et al., 2013: 221; Pugh, 2014). One thing is clear: resilience has an extensive reach. It is perhaps unsurprising, therefore, that it has begun to penetrate the humanitarian system.

The 2016 World Disasters Report Resilience: Saving Lives Today, Investing for Tomorrow is a good illustration, making a sustained case for resilience. The basic idea is a shift of focus. Rather than responding to human needs after a disaster, the report argues, aid agencies should enable people to 'bounce back' from 'shocks' and 'stresses'. The report, as described on the back cover, makes the 'business case' for resilience, suggesting that 'resilience yields financial and social benefits, as well as saving lives'. It is fitting that such an argument should be found in this particular report, which is published annually by the International Federation of Red Cross and Red Crescent Societies (IFRC). The series has been running since 1993, and its aim has remained the same since the first issue: discussing 
new developments in the humanitarian sector, providing facts and statistics, and advocating good practice. Since then, each yearly report has clustered around a theme. In the past five years the report has moved through urban risk, forced migration, malnutrition, technology and 'local actors'. This time it is the turn for resilience. ${ }^{1}$

Resilience is a crucial idea in contemporary humanitarianism, and this review essay explores its implications. The first section examines the notion of resilience in general, exploring its history, meaning and application to multiple fields. The second section then summarizes the scholarly critiques of the concept. The third section examines the attraction of resilience to humanitarians, and the fourth section explores the main criticisms of resilience that emerge from within the aid industry. Throughout the article this assessment draws on arguments from the 2016 World Disasters Report to set up the main argument in the fifth and final section. Resilience, this essay points out, is simultaneously accused of being politicizing and depoliticizing. The scholarly critique suggests that resilience depoliticizes everything it touches, producing acquiescent subjects who are discouraged from protest. The practitioner critique, on the other hand, suggests that resilience politicizes relief by focusing mistakenly on systems, structures and states. Both cannot be true. This is the paradox of resilience.

\section{RESILIENCE: HISTORY AND USES}

Resilience is derived from the Latin resilio, meaning to jump back. Its origins can be found in engineering, where it has long been used to describe the capacity of a material to return to its former shape after a stress or pressure (de Bruijne et al., 2010). In the 1970s the term was adopted in ecology and popularized in the work of Crawford Holling, who, in 1973, published an influential paper entitled the 'Resilience and Stability of Ecological Systems' (Holling, 1973). His argument was simple and powerful. Against the prevailing and rather mechanistic understanding of ecological stability, Holling developed a theory of complex adaptation. He argued that living systems can change even after they seem to have been irreparably damaged. His theory was not so much that an ecological system can bounce back and return to a previous state of equilibrium, but that an ecosystem can adapt and remain cohesive even while undergoing extreme stress (Walker and Cooper, 2011).

\footnotetext{
${ }^{1}$ For more on the aims and history of the World Disasters Report series, see www.ifrc.org/en/publications-andreports/world-disasters-report/wdr1993-1999/. The series is the product of 'independent experts' who 'present a body of research' relating to new 'challenges, trends and innovations' in humanitarianism.
} 
Alongside such 'social-ecological resilience' thinking, another use for the term emerged in the late 1970s and early 1980s. This has been labelled 'psycho-social resilience' (Welsh, 2014: 16-17). Whereas social-ecological resilience focused on a holistic understanding of adaptable systems, psycho-social resilience focused more on the individual and their coping mechanisms. These theories originated in studies of child development, exploring the way people 'bounced back' from adversity (Murphy, 1974). A classic example is Werner and Smith's study, Vulnerable but Invincible (1982), with a title that neatly captures the dynamic of resilience theories. This focus on individual, psychological resilience has expanded in recent years and is, if anything, even more widespread than before. It has generated a raft of self-help books with titles like The Resilience Factor (Reivich and Shatté, 2002), The Power of Resilience (Brooks and Goldstein, 2004), and Resilience: Bounce Back from Whatever Life Throws at You (Clarke and Nicholson, 2010).

Alongside the system-level ecological application and the individual-level psychological one, there is a third body of resilience thinking, which relates more to governance. This has become particularly influential in the last decade or so, especially since the attacks of 11 September 2001. As an idiom of governance, resilience centres on the need for each individual to anticipate risks. It has become an organizing principle for societies, to produce 'aware and adaptable' citizens and make the nation more secure. Such an approach is particularly apparent in the USA's National Security Strategy (2007) and the UK's Civil Contingencies Act (2004). ${ }^{2}$ Instead of articulating specific threats to the polity and devising concrete strategies, these documents advise openness to all possibilities. They shift responsibility for security onto individuals, who are counselled to be resilient, constantly vigilant against possible threats (Adey and Anderson, 2011; Coaffee, 2010; Lentzos and Rose, 2009).

Through its use in security governance, resilience burst into the world of humanitarianism, and over the past decade major donors and intergovernmental organizations have started emphasizing resilience in their aid strategies. In 2011, for example, the UK's Department for International Development adopted a new policy entitled Saving Lives, Preventing Suffering and Building Resilience (DFID, 2011b). This was followed by a report, Defining Disaster Resilience, which declared that resilience was DFID’s 'core approach to tackling disasters' (DFID, 2011a: 5). In 2012, the European Union (EU) made a similar statement, entitled The EU Approach to Resilience, which declared that resilience should be a

\footnotetext{
${ }^{2}$ It is worth noting that the concept of resilience also appeared in the USA's security policy much earlier, just after the 1974 oil crisis. See Walker and Cooper, 2011: 153.
} 
central aim of EU external assistance (European Commission, 2012). The Swedish International Development Cooperation Agency (SIDA) emphasized resilience in their 2012 operational plan, issuing a series of subsequent reports, such as Resilience, Risk and Vulnerability (Christoplos et al., 2012). Resilience featured as a theme in the World Bank's publications on climate change, and it became central to a prominent multi-agency report on the Roots of Resilience (UNDP et al., 2008; World Bank, 2013). The UN Secretary General extended the metaphor in his High-Level Panel on Global Sustainability, which produced a report entitled, Resilient People, Resilient Planet (UN, 2012). Interestingly for this review, the IFRC were actually one of the first agencies to embrace resilience thinking back in 2004, when a previous iteration of their World Disasters Report concerned 'community resilience' and was subtitled: 'helping communities cope with crisis’ (IFRC, 2004).

Resilience has served to unite programmes in disaster, development and climate change. The term has been defined expansively to bring diverse areas of work under a single umbrella. The European Union, for example, defined it as 'the ability of an individual, a household, a community, a country or a region to withstand, cope, adapt, and quickly recover from stresses and shocks such as violence, conflict, drought and other natural disasters without compromising long-term development' (European Commission, 2016: 1). This is a capacious definition, to say the least. DFID (2011a: 6) adopted a similar approach, declaring that resilience is 'the ability of countries, communities and households to manage change, by maintaining or transforming living standards in the face of shocks or stresses - such as earthquakes, drought or violent conflict — without compromising their long-term prospects'.

In contrast, UNDP has taken a simpler approach, describing resilience as 'the capacity to adapt and to thrive in the face of challenge'. This report suggested that resilience can work in three registers. First, people 'can become more economically resilient — better able to face economic risks'. Second, they 'can become more socially resilient — better able to work together for mutual benefit'. Third, 'the ecosystems they live in can become more biologically resilient', becoming 'more productive and stable' (UNDP et al., 2008: ix). From economics and society, to biology and ecology, resilience has clearly become a wide set of strategies. In 2013, Time magazine declared resilience to be a 'buzzword of the year' (Pugh, 2014: 313).

\section{THE SCHOLARLY CRITIQUE}


As resilience grew in importance, so did the inevitable backlash. The standard line, developed across a number of academic disciplines simultaneously, was that resilience was a form of ‘embedded neoliberalism’ (Corry, 2014; Dean, 2014; Joseph, 2013). It may look like an empty metaphor, the argument goes, but it reveals a great deal about underlying shifts in governance. Walker and Cooper (2011) wrote one of the first articles to make this argument, tracing the origins of resilience to Hayek and the Chicago School. Mark Duffield (2012a) made a similar move, examining its connection to modernist decline and the end of state planning. Jonathan Pugh (2014) and David Chandler (2013) argued that the rise of resilience indicates the fall from grace of the liberal state-building project, as Western powers promoted individual resilience rather than democratic institutions on their own model. The theme in this literature is clear: resilience represents the triumph of a neoliberal world, where 'resilient subjects' are encouraged to accept and adapt a world of endless risk (Evans and Reid, 2013).

There are four distinctive arguments in the scholarly critique of resilience, which concern knowledge, pessimism, self-government and politics. The first concerns knowledge. Resilience, the argument goes, is about accepting the unknowable. It is about adapting to ever-changing, enigmatic risks. It is, therefore, a retreat from older ideals of perfect knowledge and modernist control, a rejection of approaches that seek to predict events and isolate threats through hierarchical chains of command (Duffield, 2012a: 478-80). The 'resilience' approach, in contrast, focuses on adaptability. It no longer seeks to know the nature of threats. It assumes that we will never truly understand the threats we face or how they will affect us. In the words of Pugh (2014: 316), resilience is oriented around the basic idea that 'life itself is less governable than we previously thought'. This is, in effect, government based on the unknown.

The second argument is all about pessimism. It suggests that resilience involves abandoning ideas of progress. Mark Duffield (2012b) makes the point particularly clearly when he argues that resilience has led to a fundamental shift in attitudes to emergency. Emergencies, he argues, used to be presented as an interruption to progress, a moment of exceptional crisis that could be contained. Now, emergencies are presented as an ever-present possibility: evidence that we live in state of constant threat, which the state cannot control. Nations cannot hope to build security for their citizens, so they adopt the mantra of resilience instead. 'The state now assumes that one of its key tasks is to imagine the worst-case scenario, the coming catastrophe, the crisis-to-come, the looming attack, the emergency that could happen, might happen and probably will happen, all in order to be better prepared', writes Neocleous (2013: 4). This leads to 'a constant re-imagining of the myriad ways in 
which that threat might be realized'. It involves a fundamental pessimism about the state's ability to act.

The third argument concerns self-government. It suggests that resilience shifts responsibility from states to individuals. Perhaps counter-intuitively, this is presented as a good thing (Evans and Reid, 2013). There may be a fundamental pessimism about the capacity of the state to insulate citizens from risk, but there is a fundamental optimism about the wonderful things that can follow from embracing that risk as individuals. Rather than seeing vulnerability as a problem, it is presented as an opportunity. Rather than the limitations of the state being lamented, they are embraced. In the resilience framework, the state is presented as an obstacle to human flourishing, and our exposure to danger as both inevitable and creative (Chandler, 2013; Reid, 2010: 404; Welsh, 2014: 19).

The fourth and most important argument is that resilience is dangerously depoliticizing. It makes us quiescent. Rather than protesting threats to our livelihoods, these threats are embraced as inevitable. As Neocleous (2013: 7) puts it, this means that 'resilience is by definition against resistance. Resilience wants acquiescence.' Brad Evans and Julian Reid agree. Resilience seems like common sense, they point out. After all, what could be wrong with empowering human beings to better face up to dangers and cope with insecurity? But this conceals a 'dark and dehumanizing agenda' beneath the veneer of common sense (Evans and Reid, 2013: 95). We should not seek to become resilient against dangers, they argue, because this involves lying down and accepting such dangers. Resilience preaches 'the impossibility and folly of thinking we might resist’. It asks that we live with danger, accepting a bleak future, an 'endemic terrain of catastrophe' (Evans and Reid, 2013: 95).

This is rousing and attractive language, but it rather overstates the case. When Neocleous (2013: 4), for example, concludes that resilience involves 'nothing less than the attempted colonization of the political imagination by the state', he goes too far. He leaves no room for nuance and presents resilience as a single phenomenon, one big picture. In fact, resilience is a patchwork of smaller pictures, used very differently in ecology, psychology, governance and international aid. Indeed, when it comes to humanitarianism, resilience carries an intricate rationale. To truly understand the attraction of resilience, therefore, we need to return to the 2016 World Disasters Report and use it to understand why humanitarian policy makers are so interested in resilience. We cannot simply assume that it is all motivated by neoliberal forces, or that there is a 'dark and dehumanising agenda' lurking beneath the façade of common sense. 


\section{RESILIENCE AND HUMANITARIANISM}

Why is resilience so attractive to humanitarian policy makers? Because it bridges the gap between development and humanitarianism. This gap first appeared as a serious problem in the mid-1980s, when 'the old division' between humanitarianism and development 'simply collapsed' (Singer, 1985: 13). The division was based on the idea that disaster was an exceptional, atypical event. Humanitarians were concerned only with containing and managing the disaster, saving individual lives and taking short-term action. They would largely bypass the state, adhere to classical principles, and refuse to be drawn into political disputes. Development workers, however, had a different role. They would take over from humanitarians after the disaster had been contained. Their job was to help societies get back onto the linear path of progress, and so they worked with the state rather than around it. They tried to establish sustainable economic, social and political structures. They built systems, not saved lives.

The protracted African crises of the 1980s revealed the problem with this division. In a number of countries such as Sudan, the 'emergency' phase never ended and communities lumbered from one crisis to the next, creating blurry lines in the aid world. Aid agencies were stuck in a swamp of complex problems, where famine, war and instability merged. Relief workers found themselves dealing with chronic rather than transitory problems: in many cases, they were providing essential services for years on end, managing hospitals in lieu of the state, or widening their activities. In turn, development agencies were unable to work in their usual manner: faced with a weak or malevolent state, they could not build sustainable systems and so channeled funding into relief work. It was difficult to distinguish development and humanitarian concerns, and the result was, in the early 1990s, a rapid expansion in literature concerning the 'relief development continuum' (Borton, 1994; Longhurst, 1994; Sollis, 1994).

The aim of this literature was not to throw out the division between the two sectors entirely, but rather to create linkages between them. Instead of throwing money into shortterm, emergency black holes, donors wanted to use funds more sustainably. The idea was simple: development aid would be used to reduce the need for emergency relief, and emergency relief would promote better development. Hopes were high, and reams were written on the subject. The old division, it was believed, would wither away, and the ‘continuum' model was followed by other attempts to break down the walls, including 
Disaster Risk Reduction (DRR), Linking Relief, Recovery and Development (LRRD), and Disaster Mitigation and Preparedness (DMP).

These attempts largely failed. As Joanna MacRae (2012) pointed out, they rarely actually addressed the entrenched division between the worlds of humanitarianism and development. This is because they built bridges rather than breaking walls. Crises were still presented as exceptional events, and the path of progress remained as an idea. Their attempts failed to acknowledge that 'normality' simply does not exist for many people around the world. That progress does not take place. As Macrae (2012: 8) put it, 'vulnerability is far from transitory', it is not unique to emergencies but is entrenched. Resilience offered a way through this impasse because it forced both humanitarians and development practitioners to reject the idea of 'normal' and 'exceptional' events and start thinking about layers of vulnerability. It also packaged this in an uplifting narrative of possibility and the power of human action in the face of entrenched and protracted problems.

The attraction of resilience, therefore, is that it promises to look comprehensively at vulnerability. Rather than seeking to 'bridge' (but retain) a humanitarian-development divide, it rethinks both sectors entirely. Rather than speaking of fragility, with all its negative associations, it emphasizes putting individuals in control of their futures. Rather than being paternalistic and neo-colonial, it seems more centred around people. Rather than giving aid in a top-down manner, it is all about people helping themselves. Macrae’s message was encapsulated in her title: 'The continuum is dead. Long live resilience!'.

The 2016 World Disasters Report is written along these lines. It calls for 'nothing short of the global paradigm shift' in the way humanitarianism is understood (p. 25). It argues that 'all our interventions, at all points along the humanitarian continuum, must seek to strengthen resilience' (p. 9). The report begins with a particularly hammy anecdote that drives home this uplifting message. The IFRC director, in the foreword to the report, writes about a man called Victor, who he found digging for water in the middle of a dry riverbed. After kneeling in the dirt next to him, the director asked what he was doing. Victor told the director that it took about an hour to draw half a gallon of dirty water, and he could be found there every day. 'This is what resilience is about', Elhadj As Sy concluded. Victor 'was not passively waiting for authorities or aid groups to provide assistance. With the limited resources that he had, he was taking action' (p.9).

As an example of optimistic thinking, this is a poor start. We are invited to admire Victor's tenacity, but end up patronizing him instead. The purpose of the anecdote is to encapsulate resilience — to emphasize Victor's agency — but in the end it only illustrates the 
restricted vision that the critical scholars warn about, putting a gloss on lamentable conditions and attempting to 'take the positives' from an appalling situation. Instead of condemning the situation Victor is in, we start by praising his resilience. We are told that 'investing in resilience is the best method we have for protecting the lives, livelihoods and dignity of the world's most vulnerable people'. There is, it seems, no alternative. 'Business as usual is no longer acceptable' (p. 8). Resilience is the way.

Each of the following chapters has a different author and, consequently, a very different feel. The first chapter offers a definition of resilience and encourages humanitarians to build development into their activities. It argues that the advantage of resilience is that it offers a 'readily-understandable approach for addressing many of the challenges faced in humanitarian aid’ (p. 11). Then, it rather confusingly suggests that the notion is actually not readily understandable because it is hard to translate (pp. 14-15). The chapter has some other problems: it contains some blunt historical assertions, such as the rather bizarre statement that 'the current aid sector [is] largely unchanged in 75 years', and some spectacular failures of logic ('by improvements in preparedness' it argues, 'many disasters have been reduced or even totally prevented', before stating immediately afterwards, 'the latter being all but impossible to measure' (p. 13)).

Chapter 2 is an improvement, examining ways to measure and evaluate resilience. It has a clear argument: that quantitative measures of resilience are reductive and destined to fail. It also contains an informed discussion about the problems that emerge when outside experts decide what resilience actually is and how to measure it. These reflections on measurement are welcome, as there are real problems with resilience becoming a technocratic approach. Chapter 3 then makes the business case for resilience, exploring its cost effectiveness for donors, states and aid agencies. It drives home the point that prevention is cheaper than cure, that disasters cause huge economic losses. This is, it seems, the heart of the report: there is too much need in the world and so we must, as an aid community, invest in prevention. The chapter concludes with the idea of a 'resilience dividend', in which we all benefit, financially, from this approach (pp. 32, 85).

To put meat on these bones, Chapter 4 focuses on anticipation: 'Getting better at getting ready', and Chapter 5 is devoted to psychosocial interventions, making the link between community resilience and 'inner resilience'. Chapter 6 is concerned with building new partnerships, making the rather obvious argument that 'achieving meaningfully resilient societies is a collective effort' (p. 33), and the final chapter, Chapter 7, looks forward, dealing with the problem of prediction that lies at the heart of this new policy area. 
What unites these chapters? At times, it seems, relatively little. The report suffers from being the product of many hands, as well as being speckled with boxes and case studies that contain more undeveloped ideas. The document lacks the coherence that can be found in the 2004 WDR, which was on precisely the same topic, just over a decade ago, from the same organization. That report was not only ahead of its time, but it contained a good deal more rigour. It built on the sustainable livelihoods approach of Chambers and Conway (1992) to examine resilience through five types of capital: natural capital (such as water, land and forests); financial capital (such as savings, income, and credit); human capital (such as knowledge, skills, and health); social capital (such as networks, relations, and trust); and physical capital (such as shelter, sanitation, and energy infrastructures). The six focused chapters covered a multitude of concrete examples.

The 2016 WDR lacks such structure and substance. By now, resilience seems not a fresh new idea, but a case of old wine in new bottles. This is even acknowledged in the report itself. On page 23 there is a brief discussion of previous efforts to 'diminish the need for relief in the long term', arguing that resilience is, in essence, a more catchy articulation of previous initiatives such as DRR, LRRD and DMP (p. 11). Indeed, the biggest advantage of resilience, at this particular moment, is that it has been accepted and promoted by the donor community. Perhaps this is the real reason for a second report on resilience. Now it has become fashionable there is an opportunity to unite behind it. This suggests something rather depressing about the WDR: it no longer seems to be setting the agenda, as it was in 2004, but has ended up chasing it instead.

\section{THE PRACTITIONER CRITIQUE}

On pages 16-18 of the World Disasters Report we find a box on the 'critiques of resilience'. It addresses a few minor issues: the problems of defining resilience, the difficulty that comes with cross-cultural communication, and a passing mention of the notion's seeming pessimism. It is not surprising that neoliberalism is absent, but the problem is that there is scant recognition of those substantial criticisms that have emerged from within the humanitarian community. Indeed, humanitarian practitioners have developed a rather different criticism of resilience, which is based not so much on the argument that resilience passes responsibility from states to individuals and encourages too little intervention, but rather on the opposite argument: that resilience is too expansive and that it pushes 
humanitarianism too far. The problem, according to many humanitarian workers, is not that that resilience is minimalist and depoliticizing, but that it is maximalist and excessively politicizing. This, the argument goes, pollutes the humanitarian imperative.

Such an argument, which can be called the 'practitioner critique', has been most robustly advanced by Médecins Sans Frontières (MSF). In a blog post from the summer of 2015, three prominent staff members at MSF made three targeted barbs at the notion of resilience. ${ }^{3}$ First, they argued, resilience was wrong-headed because humanitarianism should be involved in fixing people, not fixing systems. Resilience was an attempt to smuggle development work in by the back door; it changed humanitarian focus to building states, not saving lives. Second, they argued, resilience is a way for donors to save money: it is driven by austerity, because under the umbrella of resilience donors can spread their funds and claim many successes simultaneously: building capacity, reducing vulnerability, ensuring sustainability, as well as saving lives. Third, MSF argued, humanitarianism should be based on solid, certain, objective data that helps reduce mortality. Resilience, however, has no evidence base. It is hard to define when people are resilient and even trickier to measure how it saves any lives.

MSF's intervention generated a robust exchange of views in the blogosphere, which pitted those in favour of a classically pure humanitarianism against those who advocated its link with development. ${ }^{4}$ Some of the responses were delightfully ill-tempered: MSF summarized their argument by claiming that resilience is the 'buzzword of a floundering aid system, pushed by donors increasingly looking for cost effectiveness' ${ }^{5}$ Paul Harvey of Humanitarian Outcomes, however, responded by saying that this was 'a classic example of the MSF tendency towards sanctimonious polemic', coming from the self-declared 'guardians of pure humanitarianism in the face of a co-opted aid system' ${ }^{6}$

Beyond the name-calling, however, there was a substantive debate. MSF's position was based on the idea that development and humanitarianism are in contradiction. They argued that humanitarians should not be involved in systems and provide services because

\footnotetext{
${ }^{3}$ Whittall, J., M. Phillips and M. Hofman (2014) ‘Building Resilience by Deconstructing Humanitarian Aid’. London: Medicins Sans Frontieres. www.msf.org.uk/article/opinion-and-debate-building-resiliencedeconstructing-humanitarian-aid. Posted 6 February 2014. Last accessed 17 November 2017.

${ }^{4}$ Levine, S. (2014) 'Finally, Things have got Interesting!' http://odihpn.org/blog/finally-things-have-gotinteresting. Posted 4 March 2014. Last accessed 17 November 2017.

${ }^{5}$ Whittall, J., M. Phillips and M. Hofman (2014) 'Building Resilience by Deconstructing Humanitarian Aid'. London: Medicins Sans Frontieres. www.msf.org.uk/article/opinion-and-debate-building-resiliencedeconstructing-humanitarian-aid. Posted 6 February 2014. Last accessed 17 November 2017. ${ }^{6}$ Harvey, P. (2014) 'Should Relief Workers Even Try to Build Resilience?'. http://news.trust.org//item/20140227111713-a9tle. Posted 27 February 2014. Last accessed 17 November 2017.
} 
'the whole purpose of humanitarian aid is to kick in when there is no longer a system to develop'. ${ }^{7}$ In other words, the job of humanitarian action is purely to save lives and relieve suffering without reference to politics and structures. The writers on the other side of the debate, however, styled themselves as pragmatists. They agreed that some humanitarian agencies should maintain some degree of independence from states, but they nevertheless argued that humanitarians must engage with systemic reform where necessary. ${ }^{8}$ MSF, they responded, were being unnecessarily 'purist' (WDR, p. 27). Humanitarianism must not 'divorce itself from a need to engage with state-building and resilience agendas... [it] can’t exist in glorious isolation from systems'. ${ }^{9}$

Fundamentally the argument for resilience was presented as an issue of efficiency. Supporters of resilience argued that it made no sense to have budgets set aside for emergency work with no connection to the root causes and longer term development. As Simon Levine put it, 'what we have in the aid sector is equivalent to a completely independent ambulance service with no connection whatsoever to a hospital'. 'It doesn't make sense', he went on, 'the accident and emergency budget for a hospital... are not planned separately from the NHS'.10

It is particularly interesting that, in this debate, the classical ideals were never really questioned by the proponents of resilience. Harvey agreed that there are 'necessary limits of humanitarian action based on the core principles of neutrality, impartiality and independence,' and Levine acknowledged that 'humanitarian aid should stay at arm's length from political controversies'. The 2016 World Disasters Report also subscribed to an apolitical, neutral humanitarian space, reproducing the fundamental principles of the Red Cross and arguing that 'building resilience is a logical extension of the humanitarian imperative' (pp. 8-9). For purists, this seems disingenuous. By engaging in resilience, one is already pushing humanitarianism beyond the minimal act of saving lives. Resilience contains a vision of how society should be organized, how people should act, and how resources should be shared. These are clearly political issues. It seems, therefore, that the proponents of

\footnotetext{
${ }^{7}$ Whittall, J. (2014) 'Either... Or - Building resilience is still not compatible with humanitarian aid’. https://www.msf.org.uk/article/opinion-and-debate-either\%25E2\%2580\%25A6-or-building-resilience-still-notcompatible-humanitarian-aid. Posted 12 March 2014. Last accessed 17 November 2017.

${ }^{8}$ Levine, S. (2014) 'Finally, Things have got Interesting!' http://odihpn.org/blog/finally-things-have-gotinteresting. Posted 4 March 2014. Last accessed 17 November 2017.

${ }^{9}$ Harvey, P. (2014) 'Should Relief Workers Even Try to Build Resilience?'. http://news.trust.org//item/20140227111713-a9tle. Posted 27 February 2014. Last accessed 17 November 2017. ${ }^{10}$ Anyangwe, E. (2015) 'Is it Time to Rethink the Divide between Humanitarian and Development Funding?'. Article in The Guardian newspaper (4 December). hwww.theguardian.com/global-development-professionalsnetwork/2015/dec/04/funding-humanitarian-assistance-development-aid
} 
resilience wish to have their cake and eat it too. They are advocating a form of humanitarianism that engages with longer-term systemic change, whilst insisting that this is compatible with the classical humanitarian principles as well.

In the end, the dispute turned on whether humanitarianism exists in contradiction with development. The MSF position was, in essence, that it does: that humanitarianism needs to keep its distance from development in case it gets contaminated by state interests, long-term political thinking, and other impurities that divert attention from the narrow aim of saving human lives. For the proponents of resilience, however, the humanitarian-development divide is the problem because it restricts thinking and just leads to ever-increasing aid budgets and never ending crises. As far as they are concerned, humanitarians cannot keep cutting and running from one crisis to the next. They need to stop the disasters from occurring in the first place, which involves addressing underlying vulnerabilities and root causes.

\section{THE RESILIENCE PARADOX}

If we look back at the scholarly and the practitioner critiques, we begin to see something strange going on. The scholarly argument was that resilience is depoliticizing, that resilience is 'against resistance'. The practitioner critique, however, makes the opposite point: that resilience is damaging because it is hyper-political, that it disrupts and contaminates classical humanitarianism. To put this another way, the essence of the scholarly argument is that resilience shifts attention from the state to the individual and encourages us to embrace precarity. The essence of the practitioner argument, however, is that resilience shifts attention from the individual to the state. Rather than attending to individuals, resilience advises humanitarian workers to reform states and systems.

Who is right? Both sides are wrong, but in different ways. The critical scholarship is wrong to suggest that academics can identify a deeply political project when everyone else is blinded. This argument places no faith in the ability of ordinary people to see how they are being acted upon. The critical scholars argue that dark and insidious forces lie behind a widely accepted and 'common sense' idea (Brassett et al., 2013: 226; Evans and Reid, 2013: 95), but this, to be clear, is humbug. The very existence of the practitioner critique demonstrates that scepticism is widespread. Many of the radical scholars are peddling a barely revised version of Marxian false consciousness, seeing a world of passive, unwitting 
dupes of power, when nobody is really that oblivious. Resilience is quite clearly an attempt to engage in politics by other means.

The practitioner critique, however, is wrong in another way. It is wrong in suggesting that only resilience is hyper-political, and that a more 'pure' humanitarian action can avoid such a fate. Practitioners in organizations like MSF are peddling their own myths, not least the fiction of a classical humanitarianism that remains untainted by politics, a pure form of humanitarianism that is focused on the simply moral act of saving lives. This, to be clear, is also humbug. There are many studies that stress the deeply political nature of the humanitarian project and their political effects. Humanitarians can protest all they like, insisting that they have no politics and are just interested in saving human lives, but it is obvious that humanitarianism is built on a set of political values and has supremely political effects.

Where does this leave us? With two, historically constructed divisions, which stop the debate from progressing. On the one hand, we have a division between humanitarianism and politics, which goes back to the very foundation of the Red Cross in the middle of the $19^{\text {th }}$ century. On the other hand, we have a division between humanitarianism and development, which goes back to the colonial encounter. Both divisions are constructed, but it remains difficult to unravel them; the history is too long. Development emerged from colonial attempts to civilize the natives; humanitarianism was born out of the need to contain conflict and disaster. Development engages with governments to build their effectiveness; humanitarianism avoids national governments to get aid directly to people in need. Development is funded on a 3-5 year cycle; humanitarianism is funded from year to year. Perhaps most importantly, the two worlds have very different cultures, which have been delightfully stereotyped by Tony Vaux (2001: 77) as ‘cowboys vs pinkoes’ ${ }^{11}$

Regardless of how much we question these divisions, the two sectors have maintained very different mentalities and ways of working over the years (Bradshaw, 2016). It is difficult

\footnotetext{
${ }^{11}$ Vaux was actually quoting Nicholas Stockton, who observed: 'I have frequently heard the development lobby dismiss the relief people as a bunch of cowboys and boneheads. Likewise, I have heard the relief lobby dismissing the development people as a bunch of dithering pinkoes who couldn't fight their way out of a paper bag. The conflict spills over into arguments about recruitment policies (developers for equal-opportunities, the relievers against), staff training and development (developers for, relievers against), workshops and conferences (relievers usually dismissive, 'it's just a lot of bloody talk'), technology (developers always suspicious; relievers simply interested to know whether it will work), social science (developers for, relievers highly suspicious), gender (relievers: 'what is it?')... and so on.' (Vaux, 2001: 77). In Bradshaw (2016: 3) some of the most memorable lines repeated this age-old division, with one humanitarian saying that development workers want to 'make sure you know the answer to the meaning of life and then construct a weird log-frame that tries to explain it poorly... Just odd.... I'm here to change the world. I'm not here to sit on my ass...' In return, one development worker accused humanitarians of swooping in and 'stomping' on the government. They 'grabbed some money, did some immediate work and six months later were gone’.
} 
to separate them, but perhaps we should not try. After all, the desire to link relief and development is driven by the mistaken idea that everyone is concerned about the same things. Resilience suggests that aid workers are all one happy family trying to promote well-being, when they are not. Aid workers fight and disagree. They have politics, but they disguise them. They contradict themselves and each other. Our task is not to shove this diversity into a single box or melt it all into a murky soup of resilience. Rather, the task is to understand these differences, articulate them more clearly, and learn what they can achieve in different contexts. ${ }^{12}$ We need to resist resilience, but not because it politicizes the world of aid, nor because it is depoliticizing, but because it is too cosy, too diffuse, too prone to fuzzy thinking. The best response is not to argue that there is an insidious agenda lurking beneath this bright new concept, but to argue that it supresses the richness, diversity and radicalism of humanitarianism that is increasingly under threat.

\footnotetext{
${ }^{12}$ I recently argued that we should question the distinction between humanitarianism and politics to open up new forms of activism and solidarity (Scott-Smith, 2016). The rise of resilience demands a different tactic. We need to maintain the distinction between humanitarianism and development, because if humanitarian activities are all merged under another buzzword that is uplifting but ultimately meaningless, creative possibilities may actually be reduced.
} 


\section{REFERENCES}

Adey, P. and B. Anderson (2011) 'Event and Anticipation: UK Civil Contingencies and the Space - Times of Decision', Environment and Planning A 43(12): 2878-99.

Borton, J. (1994) 'The Upsurge of Interest in the "Relief-Development Continuum”: What Does It Mean?', Humanitarian Practice Network: 8-9.

Bradshaw, S. (2016) 'Bridging the Humanitarian-Development Divide’, Solutions Alliance Roundtable Report, 9-10 February. Brussels: Solutions Alliance. http://eprints.mdx.ac.uk/19583/1/2016-02-03FinalSarahBradshawBridging\%20\%281\%29.pdf

Brassett, J. et al. (2013) 'Introduction: An Agenda for Resilience Research in Politics and International Relations', Politics 33(4): 221-28.

Brooks, R.B. and S. Goldstein. (2004) The Power of Resilience: Achieving Balance, Confidence and Personal Strength in Your Life. Chicago, IL: Contemporary Books. de Bruijne, M., A. Boin and M. van Eten (2010) 'Resilience: Exploring the Concept and its Meanings', in L.K. Comfort, A. Boin and C. Demchak (eds) Designing Resilience: Preparing for Extreme Events, pp. 13-32. Pittsburgh, PA: University of Pittsburgh Press.

Chambers, R. and G. Conway (1992) 'Sustainable Rural Livelihoods: Practical Concepts for the 21st Century’. IDS Discussion Paper 296. Brighton: Institute of Development Studies.

Chandler, D. (2013) 'International Statebuilding and the Ideology of Resilience’, Politics 33(4): 276-86.

Christoplos, I., M. Novaky and Y. Aysan (2012) 'Resilience, Risk and Vulnerability at Sida Final Report', Stockholm: Swedish International Development Cooperation Agency. http://www.sida.se/English/publications/Publication_database/

Clarke, J. and J. Nicholson (2010) Resilience: Bounce back from Whatever Life Throws at You. Bath: Crimson Publishing Ltd.

Coaffee, J. (2010) 'Protecting Vulnerable Cities: The UK's Resilience Response to Defending Everyday Urban Infrastructure', International Affairs 86(4): 939-54.

Corry, O. (2014) 'From Defense to Resilience: Environmental Security beyond Neoliberalism', International Political Sociology 8(3): 256-74.

Dean, M. (2014) 'Rethinking Neoliberalism', Journal of Sociology 50(2): 150-63.

DFID (2011a) ‘Defining Disaster Resilience: A DFID Approach Paper’. Department for International Development, 
London. https://www.gov.uk/government/publications/defining-disaster-resilience-adfid-approach-paper/

DFID (2011b) ‘Saving Lives, Preventing Suffering and Building Resilience’, Department for International Development, London. https://www.gov.uk/government/publications/saving-lives-preventing-sufferingand-building-resilience

Duffield, M. (2012a) ‘Challenging Environments: Danger, Resilience and the Aid Industry’, Security Dialogue 43(5): 475-92.

Duffield, M. (2012b) 'How did we become Unprepared?'. Paper presented at HCRI Conference Humanitarianism: Past, Present and Future, University of Manchester (10 November).

European Commission (2012) 'The EU Approach To Resilience: Learning From Food Security Crises’, Communication From The Commission To The European Parliament And The Council, COM(2012) 586. Brussels: European Commission. http://ec.europa.eu/echo/files/policies/resilience/com_2012_586_resilience en.pdf

European Commission (2016) 'Factsheet: Building Resilience: the EU's Approach’. Brussels: Development and Cooperation Humanitarian Aid and Civil Protection. http://ec.europa.eu/echo/files/aid/countries/factsheets/thematic/resilience_en. pdf

Evans, B. and J. Reid (2013) 'Dangerously Exposed: The Life and Death of the Resilient Subject', Resilience 1(2): 83-98.

Holling, C. (1973) 'Resilience and Stability of Ecological Systems', Annual Review of Ecology and Systematics 4(1): 1-23.

IFRC (2004) 'World Disasters Report 2004: From Risk to Resilience: Helping Communities Cope With Crisis', Geneva: International Federation of Red Cross and Red Crescent Societies.

Joseph, J. (2013) ‘Resilience as Embedded Neoliberalism: A Governmentality Approach’, Resilience 1(1): 38-52.

Lentzos, F. and N. Rose (2009) 'Governing Insecurity: Contingency Planning, Protection, Resilience’, Economy and Society 38(2): 230-54.

Longhurst, R. (1994) 'Conceptual Frameworks for Linking Relief and Development', IDS Bulletin 25(4): 17-23. 
Macrae, J. (2012) 'The Continuum is Dead, Long Live Resilience', NGO Voice Newsletter: Voice Out Loud(15): 8-10.

Murphy, L. (1974) 'Coping, Vulnerability, and Resilience in Childhood', in G.V. Coelho et al. (eds) Coping and Adaptation, pp. 47-68. New York: Basic Books.

Neocleous, M. (2013) 'Resisting Resilience', Radical Philosophy 178: 2-7.

Pugh, J. (2014) 'Resilience, Complexity and Postliberalism’, Area 46(3): 313-19.

Reid, J. (2010) 'The Biopoliticization of Humanitarianism: From Saving Bare Life to Securing the Biohuman in Post-interventionary Societies', Journal of Intervention and Statebuilding 4(4): 391-411.

Reid, J. (2013) 'Interrogating the Neoliberal Biopolitics of the Sustainable DevelopmentResilience Nexus', International Political Sociology 7(4): 353-67.

Reivich, K. and A. Shatté (2002) The Resilience Factor: Seven Essential Skills for Overcoming Life's Inevitable Obstacles. New York: Broadway Books.

Scott-Smith, T. (2016) 'Humanitarian Dilemmas in a Mobile World', Refugee Survey Quarterly 35(2): 1-21.

Singer, H.W. (1985) ‘Some Problems of Emergency Food Aid for Sub-Saharan Africa’, IDS Bulletin 16(3).

Sollis, P. (1994) 'The Relief-Development Continuum: Some Notes on Rethinking Assistance for Civilian Victims of Conflict', Journal of International Affairs 47(2): 45171.

UN (2012) Resilient People, Resilient Plant: A Future Worth Choosing, The Report of the United Nations Secretary-General's High-Level Panel on Global Sustainability, 20102012, New York: United Nations. https://en.unesco.org/system/files/GSP_Report_web_final.pdf

UNDP, UNEP, World Bank, and World Resources Institute (2008) Roots of Resilience:

Growing the Wealth of the Poor. Washington, DC: World Resources Institute. https://www.wri.org/sites/default/files/pdf/world_resources_2008_roots_of_resi lience_front.pdf

Vaux, T. (2001) The Selfish Altruist: Relief Work in Famine and War. London: Earthscan. Walker, J. and M. Cooper (2011) 'Genealogies of Resilience: From Systems Ecology to the Political Economy of Crisis Adaptation’, Security Dialogue 42(2): 143-60.

Welsh, M. (2014) 'Resilience and Responsibility: Governing Uncertainty in a Complex World', The Geographical Journal 180(1): 15-26. 
Werner, E. and R. Smith (1982) Vulnerable, but Invincible: A Longitudinal Study of Resilient Children and Youth. New York: McGraw-Hill.

World Bank (2013) Turn Down the Heat: Climate Extremes, Regional Impacts, and the Case for Resilience. Washington, DC: World Bank.

\section{Author biography}

Tom Scott-Smith is Associate Professor of Refugee Studies and Forced Migration at the University of Oxford (3 Mansfield Road, Oxford, OX1 3TB, tom.scott-smith@qeh.ox.ac.uk). He is a specialist in the ethnographic and historical study of humanitarian relief and is currently finishing a book on the history of emergency nutrition. 